\title{
Atomistic Simulations of the Defect Chemistry and Self-Diffusion of Li-ion in $\mathrm{LiAlO}_{2}$
}

\author{
N. Kuganathan 1,2,*iD, J. Dark ${ }^{2}$, E.N. Sgourou ${ }^{3,4}$, Y. Panayiotatos $4 \mathbb{( D}$ and A. Chroneos ${ }^{1,2} \mathbb{D}$ \\ 1 Department of Materials, Imperial College London, London W7 2AZ, UK \\ 2 Faculty of Engineering, Environment and Computing, Coventry University, Priory Street, \\ Coventry CV1 5FB, UK \\ 3 Solid State Physics Section, University of Athens, Panepistimiopolis Zografos, 15784 Athens, Greece \\ 4 Department of Mechanical Engineering, University of West Attica, 12210 Athens, Greece \\ * Correspondence: n.kuganathan@imperial.ac.uk or ad0636@coventry.ac.uk
}

Received: 28 June 2019; Accepted: 25 July 2019; Published: 27 July 2019

\begin{abstract}
Lithium aluminate, $\mathrm{LiAlO}_{2}$, is a material that is presently being considered as a tritium breeder material in fusion reactors and coating material in Li-conducting electrodes. Here, we employ atomistic simulation techniques to show that the lowest energy intrinsic defect process is the cation anti-site defect (1.10 eV per defect). This was followed closely by the lithium Frenkel defect $(1.44 \mathrm{eV}$ per defect), which ensures a high lithium content in the material and inclination for lithium diffusion from formation of vacancies. Li self-diffusion is three dimensional and exhibits a curved pathway with a migration barrier of $0.53 \mathrm{eV}$. We considered a variety of dopants with charges $+1(\mathrm{Na}, \mathrm{K}$ and $\mathrm{Rb}),+2(\mathrm{Mg}, \mathrm{Ca}, \mathrm{Sr}$ and $\mathrm{Ba}),+3(\mathrm{Ga}, \mathrm{Fe}, \mathrm{Co}, \mathrm{Ni}, \mathrm{Mn}, \mathrm{Sc}, \mathrm{Y}$ and $\mathrm{La})$ and +4 (Si, Ge, Ti, Zr and $\mathrm{Ce}$ ) on the $\mathrm{Al}$ site. Dopants $\mathrm{Mg}^{2+}$ and $\mathrm{Ge}^{4+}$ can facilitate the formation of Li interstitials and $\mathrm{Li}$ vacancies, respectively. Trivalent dopants $\mathrm{Fe}^{3+}, \mathrm{Ni}^{3+}$ and $\mathrm{Mn}^{3+}$ prefer to occupy the $\mathrm{Al}$ site with exoergic solution energies meaning that they are candidate dopants for the synthesis of $\mathrm{Li}(\mathrm{Al}, \mathrm{M}) \mathrm{O}_{2}$ $(\mathrm{M}=\mathrm{Fe}, \mathrm{Ni}$ and $\mathrm{Mn})$ compounds.
\end{abstract}

Keywords: $\mathrm{LiAlO}_{2}$; defects; Li diffusion; dopants; atomistic simulation

\section{Introduction}

The ever-increasing demand for energy generated, initiated further research into alternate methods of renewable energy production and storage methodologies for the power production. In that respect, Li-based ceramics are technologically important and considered by the community for applications ranging from nuclear fusion to batteries [1-8]. $\mathrm{LiAlO}_{2}$, a lithium based ceramic material, has been considered with the prospect of being used as a tritium breeder material in magnetic confined nuclear fusion reactors after promising initial research regarding the physical and thermodynamic properties of the material as well as the potential tritium breeding ratio (TBR) [8,9]. In addition, this material has great potential as a coating material in Li-conducting electrodes [10].

Previous studies have highlighted the importance of atomic scale calculation to gain insights on the defect processes (intrinsic defect processes, doping and diffusion) of oxides for energy applications [11-15]. Previous experimental and theoretical studies determined a wide range of activation energies for Li self-diffusion in $\gamma-\mathrm{LiAlO}_{2}(0.50-1.26 \mathrm{eV})$ [16-22]. Additionally, there are no systematic studies of the intrinsic defect processes and doping in this material. In the present study, we have employed atomistic simulations to investigate the structure, intrinsic defect processes, Li self-diffusion and the introduction of dopants. 


\section{Computational Methods}

The present computational study was based on classical pair-wise potential calculations to describe $\mathrm{LiAlO}_{2}$ via the General Utility Lattice Program (GULP) code [23,24]. In the present approach, the total energy (lattice energy) is determined by long range (i.e., Coulombic) and short range [i.e., electron-electron repulsive and attractive intermolecular forces (van der Waals forces)]. The latter were modelled using Buckingham potentials (refer to the supplementary information). The van der Waals forces arising from the spontaneous formation of instantaneous dipoles are very important as the formation energy results are sensitive to those forces. The present modelling approach takes into the account of Van der Waals forces as a function of the interatomic distance (r) [23,24]. Two-body Buckingham potential mentioned in the supplementary information consists of two parts. The first part of the equation represents the Pauli repulsion (electron-electron) and the second part denotes the van der Waals interaction. Ionic positions and lattice parameters were relaxed using the Broyden-Fletcher-Goldfarb-Shanno (BFGS) algorithm [24]. Convergence criteria dictated that in relaxed configurations, forces on each atom was $<0.001 \mathrm{eV} / \AA$. To introduce point defects in the lattice we used the Mott-Littleton methodology [25] similarly to recent work [26-28]. It is established that although the present methodology may overestimate the defect formation enthalpies at the dilute limit, the trends will be unchanged [29]. In a thermodynamic perspective defect parameters can be described by comparing the real (i.e., defective) crystal to an isobaric or isochoric ideal (i.e., non-defective) crystal. Defect formation parameters can be interconnected through thermodynamic relations $[30,31]$, with the present atomistic simulations corresponding to the isobaric parameters for the migration and formation processes [32-34].

\section{Results}

\subsection{Crystal Structure, Intrinsic Defect Processes and Li Diffusion}

The $\mathrm{LiAlO}_{2}$ crystal structure considered in the present study is the tetragonal $\gamma$-phase (Figure 1) with lattice parameters $\mathrm{a}=\mathrm{b}=5.1687 \AA, \mathrm{c}=6.2679 \AA$, and $\alpha=\beta=\gamma=90^{\circ}$ [35]. This crystal structure consists of $\mathrm{LiO}_{4}$ and $\mathrm{AlO}_{4}$ tetrahedra. They are inter-connected via edge and corner sharing to form three dimensional channels. The calculated structural parameters are given in Table 1 and it can be seen that there is excellent agreement with experiment [35] validating the potentials (refer to Table S1 in the Supplementary Materials) used in this study.

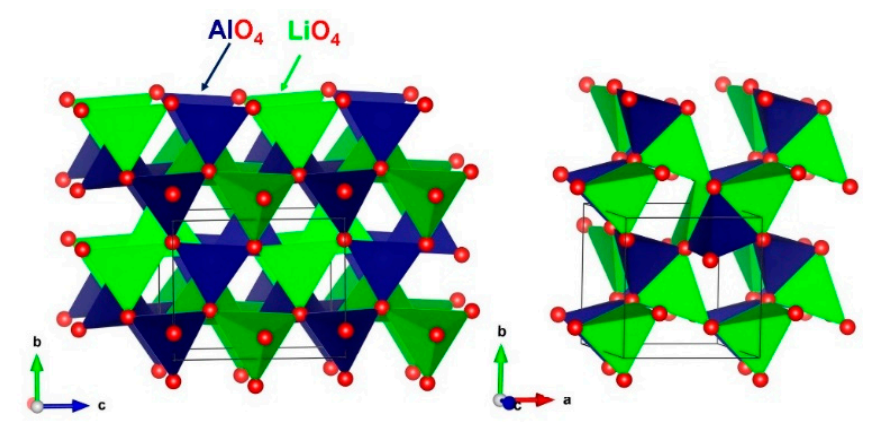

Figure 1. Crystal structure of $\mathrm{LiAlO}_{2}$ (space group $\mathrm{P}_{4}{ }_{1}{ }_{1} 2$ ).

Table 1. Calculated structural parameters for $\mathrm{LiAlO}_{2}$ (space group $\mathrm{P}_{1} 2_{1} 2$ ) as compared to the experimental determinations [35].

\begin{tabular}{cccc}
\hline Parameter & Exp & Calc & $|\Delta|(\%)$ \\
\hline $\mathrm{a}=\mathrm{b}(\AA)$ & 5.1687 & 5.1403 & 0.55 \\
$\mathrm{c}(\AA)$ & 6.2679 & 6.3860 & 1.88 \\
$\alpha=\beta=\gamma\left({ }^{\circ}\right)$ & 90.00 & 90.00 & 0.00 \\
\hline Volume $\left[\mathrm{V}=\mathrm{a} \times \mathrm{b} \times \mathrm{c}\left(\AA^{3}\right)\right]$ & 167.4498 & 168.7370 & 0.77 \\
\hline
\end{tabular}


Next, we considered the process of calculating the defect energy required for the key intrinsic defect processes such as Frenkel, Schottky and anti-site in $\mathrm{LiAlO}_{2}$. Frenkel and Schottky defect formation energies were calculated by combining individual point defects. Frenkel energy is the sum of vacancy and interstitial energies. Schottky energy was calculated by adding appropriate vacancy energies and substracting cohesive energy. Relative energetics of these defect processes are useful in predicting the electrochemical behaviour of $\mathrm{LiAlO}_{2}$. The reaction energies for the intrinsic defect processes can be represented by using the established Kröger-Vink notation [36].

$$
\begin{gathered}
\text { Li Frenkel }: \mathrm{Li}_{\mathrm{Li}}^{\mathrm{X}} \rightarrow V_{\mathrm{Li}}^{\prime}+\mathrm{Li}_{\mathrm{i}}^{\bullet} \\
\text { Al Frenkel : } \mathrm{Al}_{\mathrm{Al}}^{\mathrm{X}} \rightarrow V_{\mathrm{Al}}^{\prime \prime \prime}+\mathrm{Al}_{\mathrm{i}}^{\bullet \bullet \bullet} \\
\text { O Frenkel : } \mathrm{O}_{\mathrm{O}}^{\mathrm{X}} \rightarrow V_{\mathrm{O}}^{\bullet \bullet}+\mathrm{O}_{\mathrm{i}}^{\prime \prime} \\
\text { Schottky }: \mathrm{Li}_{\mathrm{Li}}^{\mathrm{X}}+\mathrm{Al}_{\mathrm{Al}}^{\mathrm{X}}+2 \mathrm{O}_{\mathrm{O}}^{\mathrm{X}} \rightarrow V_{\mathrm{Li}}^{\prime}+V_{\mathrm{Al}}^{\prime \prime \prime}+2 V_{\mathrm{O}}^{\bullet \bullet}+\mathrm{LiAlO}_{2} \\
\mathrm{Li}_{2} \mathrm{O} \text { Schottky }: 2 \mathrm{Li}_{\mathrm{Li}}^{\mathrm{X}}+\mathrm{O}_{\mathrm{O}}^{\mathrm{X}} \rightarrow 2 V_{\mathrm{Li}}^{\prime}+V_{\mathrm{O}}^{\bullet \bullet}+\mathrm{Li}_{2} \mathrm{O} \\
\mathrm{Li} / \mathrm{Al} \text { antisite (isolated) }: \mathrm{Li}_{\mathrm{Li}}^{\mathrm{X}}+\mathrm{Al}_{\mathrm{Al}}^{\mathrm{X}} \rightarrow \mathrm{Li}_{\mathrm{Al}}^{\prime \prime}+\mathrm{Al}_{\mathrm{Li}}^{\bullet \bullet} \\
\mathrm{Li} / \mathrm{Al} \text { antisite (cluster) }: \mathrm{Li}_{\mathrm{Li}}^{\mathrm{X}}+\mathrm{Al}_{\mathrm{Al}}^{\mathrm{X}} \rightarrow\left\{\mathrm{Li}_{\mathrm{Li}}^{\prime \prime}: \mathrm{Al}_{\mathrm{Li}}^{\bullet \bullet}\right\}^{\mathrm{X}}
\end{gathered}
$$

The reaction energies are reported in Figure 2. The lowest intrinsic defect energy process was calculated to be the cation mixing (anti-site) in which $\mathrm{Li}$ and $\mathrm{Al}$ exchange their atomic positions. This defect was noted in various oxide materials experimentally and theoretically [37-47]. The primary reasons for this defect include experimental conditions for the preparation of as-prepared compounds and cycling of as-prepared materials particularly in battery applications. Using the Pechini sol-gel process, Dominko et al. [48] synthesised a pure orthorhombic phase of $\mathrm{Li}_{2} \mathrm{MnSiO}_{4}$. Later, Politaev et al. [39] observed a small amount of cation exchange ( $\mathrm{Li}-\mathrm{Mn})$ defect in their experimental preparation (solid-state reactions in hydrogen at $950-1150{ }^{\circ} \mathrm{C}$ ) of monoclinic phase of $\mathrm{Li}_{2} \mathrm{MnSiO}_{4}$. Nyten et al. [38] observed a shift in the potential plateau between first and second cycles in $\mathrm{Li}_{2} \mathrm{FeSiO}_{4}$ and suggested that this is due to the structural rearrangement associated with the interchange of some of the $\mathrm{Li}$ and Fe ions. The second lowest reaction energy is calculated for the Frenkel defect and this process is higher only by $0.34 \mathrm{eV}$ than the anti-site defect. This would signify the concentration of lithium vacancies and interstitials, inferring this material is suitable for use as a tritium breeder. Other defects exhibit high reaction energies meaning that they are not significant in this material.

Ion diffusion is a key issue in many energy related materials, including cathode materials for batteries. The current simulation approach has the ability to calculate Li-ion diffusion pathways together with activation energies. As experimental determination of Li-ion diffusion is quite challenging, simulation results would be useful to assist in the investigation of experimental data. The results reveal that there is a single Li local hop with the jump distance of $3.09 \AA$. The activation energy for this hop is calculated to be $0.53 \mathrm{eV}$. Long range diffusion pathway was constructed by connecting local $\mathrm{Li}$ hops. Figure 3a shows the three dimensional long range diffusion pathway with a non-linear pattern. This shows that Li-ion conduction in this material is high. In a previous theoretical study based on the molecular dynamics by Jacobs et al. [18], it is shown that Li-ion diffusion is three dimensional though the pathway is not clear enough from their calculated snapshots derived at different temperatures. Density functional theory simulations were also employed to calculate the $\mathrm{Li}$-ion diffusivity in $\gamma$ - $\mathrm{LiAlO}_{2}[21,22]$. In those calculations, Li hopping mechanisms and activation energies for different $\mathrm{Li}$-Li separations are reported. However, the information regarding the Li migration pathway (linear or non-linear) is unclear. Our simulation clearly presents the diffusion pathway that can be directly compared in experiments. 


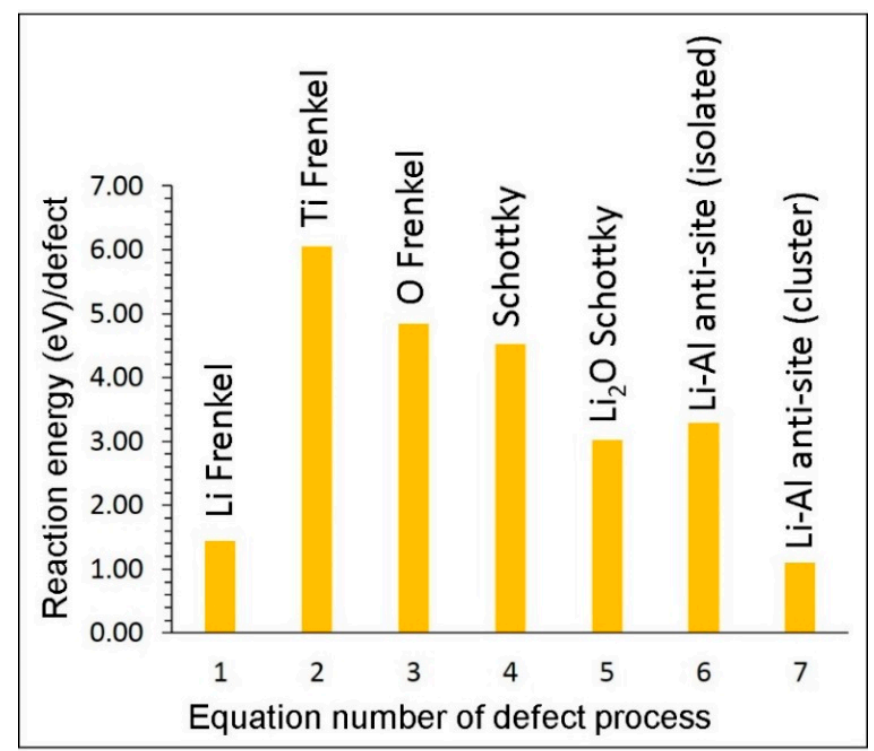

Figure 2. Energetics of intrinsic defect process calculated in tertragonal $\mathrm{LiAlO}_{2}$.
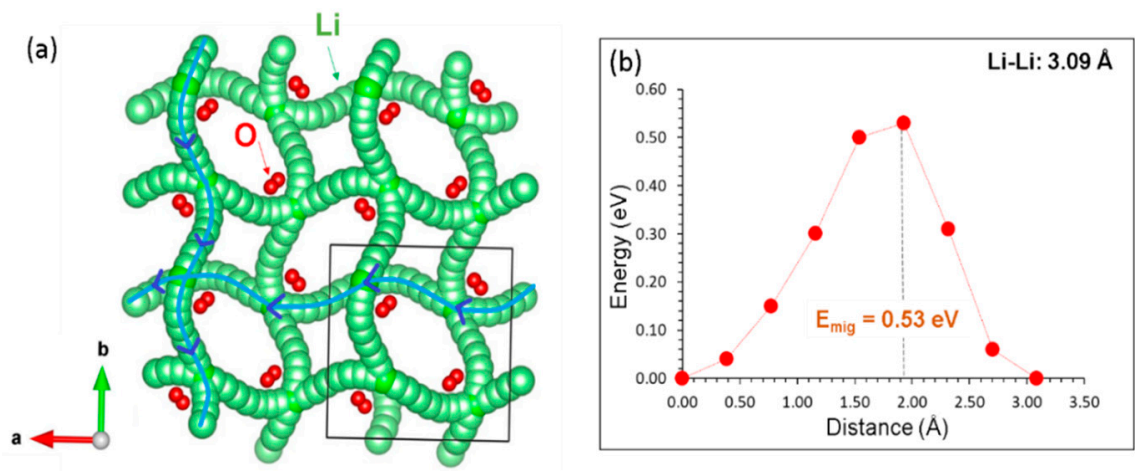

Figure 3. (a) Calculated long range three dimensional Li-ion diffusion pathways and (b) energy profile diagram for the local Li hop involved in the long range diffusion.

The activation energy calculated here $(0.53 \mathrm{eV})$ is within the range of previous theoretical studies $(0.5-0.63 \mathrm{eV})[18,21,22]$ and lower that previous experimental (NMR spectroscopy and conductivity measurements) work by Idris et al. $(0.70 \mathrm{eV})$ [17]. More direct experimental work (e.g., secondary ion mass spectrometry, SIMS) would be required to experimentally pinpoint the activation energy of $\mathrm{Li}$ self-diffusion. As was previously demonstrated, simple atomistic models can yield reliable activation energies of diffusion as compared to experiment with mechanisms compatible with DFT [49].

The calculated activation energy exceeds $0.5 \mathrm{eV}$ and it is therefore anticipated that $\mathrm{LiAlO}_{2}$ will only be a mediocre ion conductor. In Table 2 we compare the activation energies of migration of recently investigated $\mathrm{Li}, \mathrm{Na}, \mathrm{Mg}$ ion conducting oxides considered for battery applications. There is a good agreement between our calculations and experiments for some oxide materials. As mentioned earlier, experimental investigation of activation energy is often difficult. Current simulations, in addition to giving activation energy information, have the added bonus of elucidating diffusion pathways that can be useful in the interpretation of experimental data. 
Table 2. Activation energies (eV) of ion self-diffusion ( $\mathrm{Li}, \mathrm{Na}, \mathrm{Mg}$ ) in recently investigated oxides considered for battery applications.

\begin{tabular}{ccc}
\hline Material & Calculation & Experiment \\
\hline $\mathrm{LiAlO}_{2}$ & 0.53 (this study) & $0.70-1.23[17]$ \\
$\mathrm{Li}_{3} \mathrm{~V}_{2}\left(\mathrm{PO}_{4}\right)_{3}$ & $0.46-0.87[50]$ & $0.73-0.83[51]$ \\
$\mathrm{Li}_{2} \mathrm{TiO}_{3}$ & $0.51-0.72[52]$ & $0.47-0.80[53], 0.60-0.90[54]$ \\
$\mathrm{Na}_{2} \mathrm{MnSiO}_{4}$ & $0.81[55]$ & - \\
$\left.\mathrm{Na}_{3} \mathrm{~V}_{(} \mathrm{PO}_{4}\right)_{2}$ & $0.59[56]$ & - \\
$\mathrm{Na}_{3} \mathrm{Fe}_{2}\left(\mathrm{PO}_{4}\right)_{3}$ & $0.45[15]$ & - \\
$\mathrm{MgTiO}_{3}$ & $0.88[57]$ & - \\
\hline
\end{tabular}

\subsection{Solution of Dopants}

This section details the processes of monovalent, divalent, trivalent and tetravalent doping into the lithium aluminate lattice. Monovalent dopants $(R=N a, K$ and $R b)$ and divalent dopants $(\mathrm{M}=\mathrm{Mg}$, $\mathrm{Ca}, \mathrm{Sr}$ and $\mathrm{Ba}$ ) were considered on the $\mathrm{Al}$ site in order to increase the $\mathrm{Li}$ content in the form of $\mathrm{Li}$ interstitials in $\mathrm{LiAlO}_{2}$ according the following reaction equations:

$$
\begin{aligned}
& 2 \mathrm{Li}_{2} \mathrm{O}+\mathrm{R}_{2} \mathrm{O}+2 \mathrm{Al}_{\mathrm{Al}}^{\mathrm{X}} \rightarrow 2 \mathrm{R}_{\mathrm{Al}}^{\prime \prime}+4 \mathrm{Li}_{\mathrm{i}}^{\bullet}+\mathrm{Al}_{2} \mathrm{O}_{3} \\
& \mathrm{Li}_{2} \mathrm{O}+2 \mathrm{MO}+2 \mathrm{Al}_{\mathrm{Al}}^{\mathrm{X}} \rightarrow 2 \mathrm{M}_{\mathrm{Al}}^{\prime}+2 \mathrm{Li}_{\mathrm{i}}^{\bullet}+\mathrm{Al}_{2} \mathrm{O}_{3}
\end{aligned}
$$

This efficient engineering strategy can increase the lithium density in lithium-based ceramics and tune mechanical, electrical and optical properties of materials such as lithium aluminate to further increase the applicability for use as a tritium breeding material. Solution enthalpies calculated for monovalent dopants are highly endothermic $(>4.5 \mathrm{eV})$ suggesting that the doping process is quite difficult (refer to Figure 4a). Solution enthalpy gradually increases with ionic radius. High solution enthalpies are due to the larger radii of cations than that of $\mathrm{Al}^{3+}(0.53 \AA)$. In the case of divalent cations, $\mathrm{Mg}^{2+}$ is promising as the solution enthalpy of $\mathrm{MgO}$ is $-5.66 \mathrm{eV}$ (refer to Figure $4 \mathrm{~b}$ ). The highly exothermic solution enthalpy is due to the ionic radius of $\mathrm{Mg}^{2+}(0.57 \AA)$ which is closer to the ionic radius of $\mathrm{Al}^{3+}$. The other three dopants exhibit endoergic solution enthalpies, as their ionic radii significantly deviate from the ionic radius of $\mathrm{Al}^{3+}$.
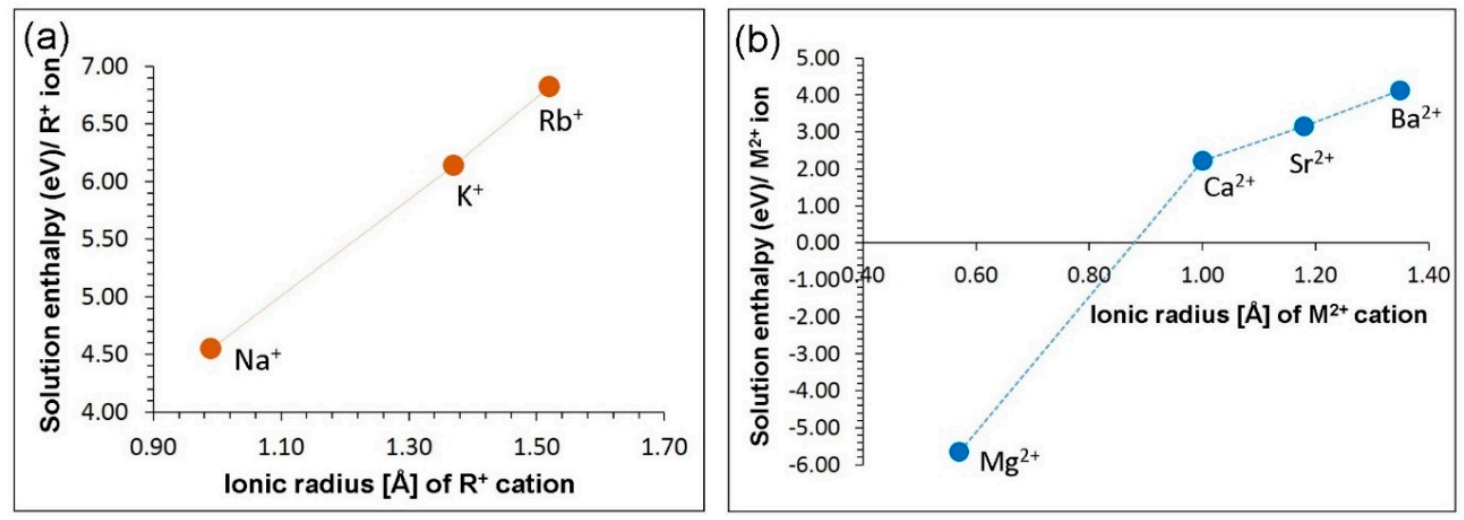

Figure 4. Solution enthalpies of (a) $\mathrm{R}_{2} \mathrm{O}(\mathrm{R}=\mathrm{Na}, \mathrm{K}$ and $\mathrm{Rb})$ with respect to the $\mathrm{R}^{+}$ionic radius and (b) $\mathrm{MO}(\mathrm{M}=\mathrm{Mg}, \mathrm{Ca}, \mathrm{Sr}$ and $\mathrm{Ba})$ with respect to the $\mathrm{M}^{2+}$ ionic radius in $\mathrm{LiAlO}_{2}$.

Next, we considered trivalent dopants $(\mathrm{X}=\mathrm{Ga}, \mathrm{Fe}, \mathrm{Co}, \mathrm{Ni}, \mathrm{Mn}, \mathrm{Sc}, \mathrm{Y}$ and $\mathrm{La})$ on the $\mathrm{Al}$ site according to the following reaction equation:

$$
\mathrm{X}_{2} \mathrm{O}_{3}+2 \mathrm{Al}_{\mathrm{Al}}^{\mathrm{X}} \rightarrow 2 \mathrm{X}_{\mathrm{Al}}^{\mathrm{X}}+\mathrm{Al}_{2} \mathrm{O}_{3}
$$


Figure 5 shows the solution enthalpies of $\mathrm{X}_{2} \mathrm{O}_{3}$. The results present nickel as the favourable isovalent dopant on the $\mathrm{Al}$ site, having the lowest solution enthalpy of $-2.03 \mathrm{eV}$ to integrate into the lattice. Solution enthalpies for both $\mathrm{Fe}^{3+}$ and $\mathrm{Mn}^{3+}$ are also negative implying that these two dopants are also worth examining experimentally. The favourable nature of potential candidate dopants $\left(\mathrm{Fe}^{3+}\right.$, $\mathrm{Ni}^{3+}$ and $\left.\mathrm{Mn}^{3+}\right)$ can be due to their ionic radii which are closer to the ionic radius of $\mathrm{Al}^{3+}(0.53 \AA)$. However, the dopant $\mathrm{Co}^{3+}$ exhibits a positive solution enthalpy though its ion radius is closer to that of $\mathrm{Al}^{3+}$ indicating other factors should be responsible. The dopants $\mathrm{Ga}^{3+}$ and $\mathrm{Sc}^{3+}$ exhibit almost zero solution enthalpies. Other dopants are not favourable as their solution enthalpies are endoergic. From $\mathrm{Mn}^{3+}$ to $\mathrm{La}^{3+}$ solution enthalpy gradually increases with ionic radius.

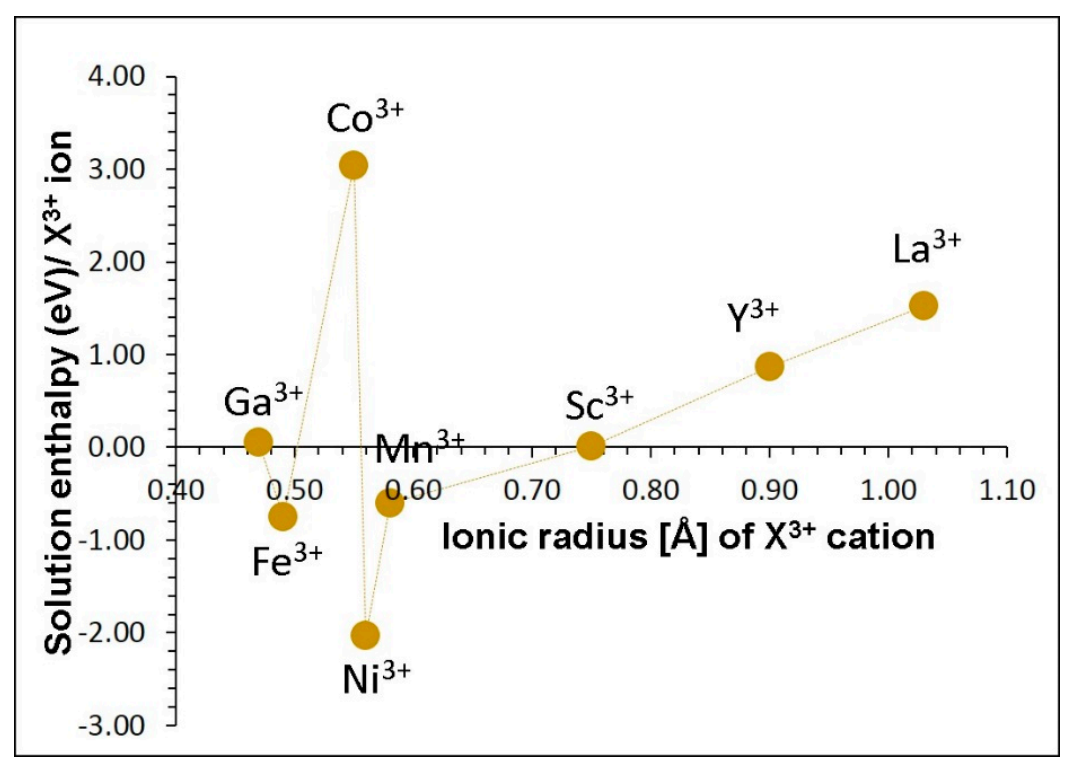

Figure 5. Solution enthalpies of $\mathrm{X}_{2} \mathrm{O}_{3}\left(X=\mathrm{Ga}, \mathrm{Fe}, \mathrm{Co}, \mathrm{Ni}, \mathrm{Mn}, \mathrm{Sc}, \mathrm{Y}\right.$ and La) with respect to the $\mathrm{X}^{3+}$ ionic radius in $\mathrm{LiAlO}_{2}$.

Finally, tetravalent dopants $(\mathrm{Y}=\mathrm{Si}, \mathrm{Ge}, \mathrm{Ti}, \mathrm{Zr}$ and $\mathrm{Ce})$ were considered on the $\mathrm{Al}$ site. This doping process will introduce additional $\mathrm{Li}$ vacancies in $\mathrm{LiAlO}_{2}$ assisting vacancy mediated self-diffusion according to the following equation:

$$
2 \mathrm{YO}_{2}+2 \mathrm{Al}_{\mathrm{Al}}^{\mathrm{X}}+2 \mathrm{Li}_{\mathrm{Li}}^{\mathrm{X}} \rightarrow 2 \mathrm{Y}_{\mathrm{Al}}^{\bullet}+2 \mathrm{~V}_{\mathrm{Li}}^{\prime}+\mathrm{Al}_{2} \mathrm{O}_{3}+\mathrm{Li}_{2} \mathrm{O}
$$

We report the solution energies in Figure 6. The results present germanium as the favourable tetravalent dopant on the aluminium site, having the lowest solution enthalpy of $1.08 \mathrm{eV}$ to integrate into the lattice. The second most stable dopant is $\mathrm{Zr}$ with the solution enthalpy of $1.54 \mathrm{eV}$. The ionic radii of these two dopants are closer to the ionic radius of $\mathrm{Al}^{3+}$. However, the high positive solution enthalpy of $\mathrm{Ti}(\sim 14 \mathrm{eV})$ is unclear though its ionic radius is somewhat closer to that of $\mathrm{Al}^{3+}$. Furthermore, this dopant cannot be doped under any condition. Both $\mathrm{Si}$ and Ce exhibit high solution enthalpies $(\sim 4 \mathrm{eV})$ due to the mismatching of their ionic radii with that of $\mathrm{Al}^{3+}$. 


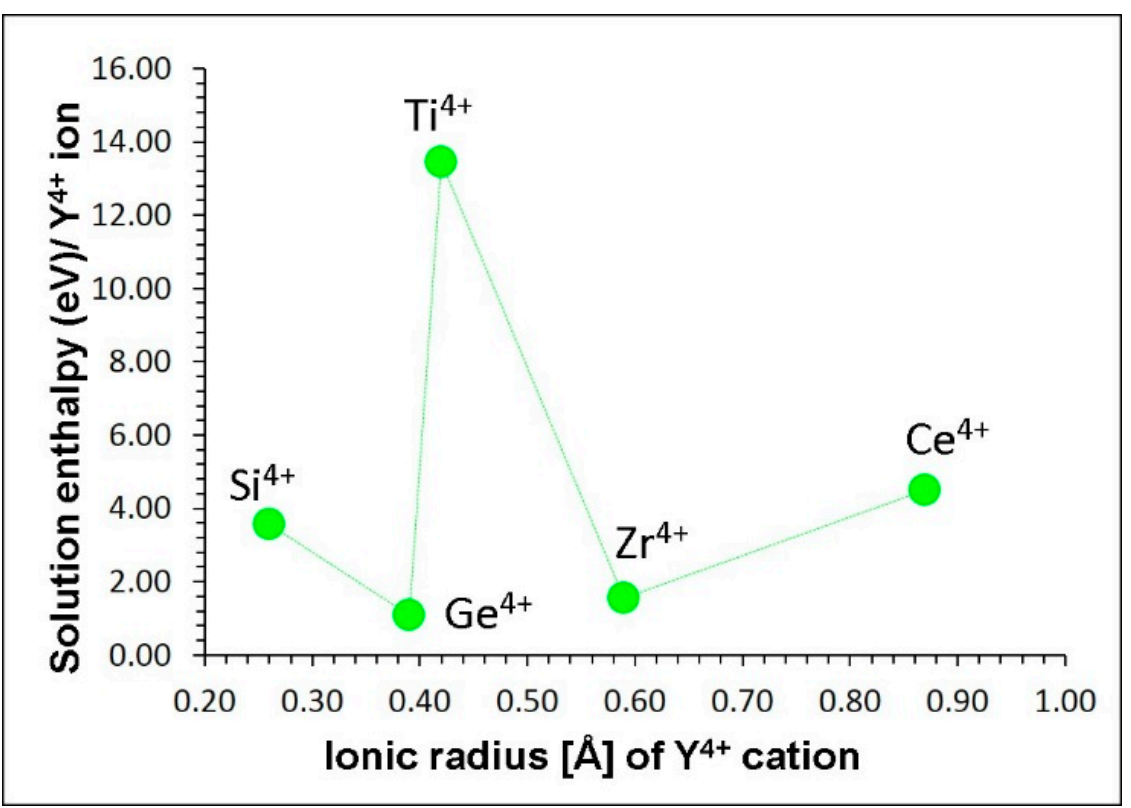

Figure 6. Solution enthalpies of $\mathrm{YO}_{2}(\mathrm{Y}=\mathrm{Si}, \mathrm{Ti}, \mathrm{Ge}, \mathrm{Zr}$ and $\mathrm{Ce})$ with respect to the $\mathrm{Y}^{4+}$ ionic radius in $\mathrm{LiAlO}_{2}$.

\section{Conclusions}

In this computational modelling investigation, we have employed static atomistic simulation techniques to study the defect processes (intrinsic disorder mechanisms and doping) and Li self-diffusion in $\mathrm{LiAlO}_{2}$. The lowest energy intrinsic defect process is the $\mathrm{Li}-\mathrm{Al}$ anti-site implying that a small concentration of $\mathrm{Li}$ on the $\mathrm{Al}$ site and $\mathrm{Al}$ on the $\mathrm{Li}$ site will be present. The long range Li-ion diffusion is three-dimensional with an activation energy of migration of $0.53 \mathrm{eV}$. Numerous dopants were considered and it is calculated that the solution of $\mathrm{GeO}_{2}$ will increase the concentration of the $\mathrm{Li}$ vacancies that are required to act as vehicles of diffusion. Furthermore, $\mathrm{Mg}^{2+}$ on the $\mathrm{Al}$ site would increase the concentration of $\mathrm{Li}$ interstitials that are necessary for the enhancement in the capacity of $\mathrm{NaAlO}_{2}$. It is anticipated that the present atomistic simulation work will encourage the further experimental investigation of $\mathrm{LiAlO}_{2}$.

Supplementary Materials: The following are available online at http:/www.mdpi.com/1996-1073/12/15/2895/s1, Table S1: Interatomic potential parameters used in the atomistic simulations of $\mathrm{LiAlO}_{2}$.

Author Contributions: Computation N.K. and J.D.; Writing, N.K. and A.C.; Analysis N.K., A.C., E.N.S. and Y.P.

Funding: This research was financially supported by the European Union's H2020 Programme under Grant Agreement no 824072-HARVESTORE.

Acknowledgments: We acknowledge Coventry University and Imperial College London for providing computing facilities.

Conflicts of Interest: The authors declare no conflict of interest.

\section{References}

1. Padhi, A.K.; Nanjundaswamy, K.S.; Goodenough, J.B. Phospho-olivines as Positive-Electrode Materials for Rechargeable Lithium Batteries. J. Electrochem. Soc. 1997, 144, 1188-1194. [CrossRef]

2. Tarascon, J.M.; Armand, M. Issues and challenges facing rechargeable lithium batteries. Nature 2001, 414, 359. [CrossRef] [PubMed]

3. Whittingham, M.S. Lithium Batteries and Cathode Materials. Chem. Rev. 2004, 104, 4271-4302. [CrossRef] [PubMed] 
4. Recham, N.; Chotard, J.N.; Dupont, L.; Delacourt, C.; Walker, W.; Armand, M.; Tarascon, J.M. A 3.6 V lithium-based fluorosulphate insertion positive electrode for lithium-ion batteries. Nat. Mater. 2009, 9, 68. [CrossRef] [PubMed]

5. Masquelier, C.; Croguennec, L. Polyanionic (Phosphates, Silicates, Sulfates) Frameworks as Electrode Materials for Rechargeable Li (or Na) Batteries. Chem. Rev. 2013, 113, 6552-6591. [CrossRef] [PubMed]

6. Islam, M.S.; Fisher, C.A.J. Lithium and sodium battery cathode materials: computational insights into voltage, diffusion and nanostructural properties. Chem. Soc. Rev. 2014, 43, 185-204. [CrossRef] [PubMed]

7. Jay, E.E.; Rushton, M.J.D.; Chroneos, A.; Grimes, R.W.; Kilner, J.A. Genetics of superionic conductivity in lithium lanthanum titanates. Phys. Chem. Chem. Phys. 2015, 17, 178-183. [CrossRef]

8. Ma, S.G.; Gao, T.; Li, S.C.; Ma, X.J.; Shen, Y.H.; Lu, T.C. Theoretical investigations on the a-LiAlO 2 properties via first-principles calculation. Fusion Eng. Des. 2016, 113, 324-330. [CrossRef]

9. Paudel, H.P.; Lee, Y.L.; Senor, D.J.; Duan, Y. Tritium diffusion pathways in $\gamma-\mathrm{LiAlO}_{2}$ pellets used in TPBAR: A first-principles density functional theory investigation. J. Phys. Chem. C 2018, 122, 9755-9765. [CrossRef]

10. Park, J.S.; Meng, X.B.; Elam, J.W.; Hao, S.Q.; Wolverton, C.; Kim, C.; Cabana, J. Ultrathin lithium-ion conducting coatings for increased interfacial stability in high voltage lithium-ion batteries. Chem. Mater. 2014, 26, 3128-3134. [CrossRef]

11. Kuganathan, N.; Islam, M.S. $\mathrm{Li}_{2} \mathrm{MnSiO}_{4}$ Lithium Battery Material: Atomic-Scale Study of Defects, Lithium Mobility, and Trivalent Dopants. Chem. Mater. 2009, 21, 5196-5202. [CrossRef]

12. Rupasov, D.; Chroneos, A.; Parfitt, D.; Kilner, J.A.; Grimes, R.W.; Istomin, S.Y.; Antipov, E.V. Oxygen diffusion in $\mathrm{Sr}_{0.75} \mathrm{Y}_{0.25} \mathrm{CoO}_{2.625}$ : A molecular dynamics study. Phys. Rev. B 2009, 79, 172102. [CrossRef]

13. Seymour, I.D.; Chroneos, A.; Kilner, J.A.; Grimes, R.W. Defect processes in orthorhombic $\mathrm{LnBaCo}_{2} \mathrm{O}_{5.5}$ double perovskites. Phys. Chem. Chem. Phys. 2011, 13, 15305-15310. [CrossRef] [PubMed]

14. Fisher, C.A.J.; Kuganathan, N.; Islam, M.S. Defect chemistry and lithium-ion migration in polymorphs of the cathode material $\mathrm{Li}_{2} \mathrm{MnSiO}_{4}$. J. Mater. Chem. A 2013, 1, 4207-4214. [CrossRef]

15. Kuganathan, N.; Chroneos, A. Defect Chemistry and Na-Ion Diffusion in $\mathrm{Na}_{3} \mathrm{Fe}_{2}\left(\mathrm{PO}_{4}\right)_{3}$ Cathode Material. Materials 2019, 12, 1348. [CrossRef] [PubMed]

16. Alessandrini, F.; Alvani, C.; Casadio, S.; Mancini, M.; Nannetti, C. In-situ tritium release (CORELLI-2 experiment) and ex-reactor ionic conductivity of substoichiometric $\mathrm{LiAlO}_{2}$ breeder ceramics. J. Nucl. Mater. 1995, 224, 236-244. [CrossRef]

17. Indris, S.; Heitjans, P.; Uecker, R.; Rolling, B. Li ion dynamics in a $\mathrm{LiAlO}_{2}$ single crystal studied by 7Li NMR spectroscopy and conductivity measurements. J. Phys. Chem. C 2012, 116, 14243-14247. [CrossRef]

18. Jacobs, J.P.; San Miguel, M.A.; Alvarez, L.J.; Giral, P.B. Lithium diffusion in $\gamma-\mathrm{LiAlO}_{2}$, a molecular dynamics simulation. J. Nucl. Mater. 1996, 232, 131-137. [CrossRef]

19. Hu, Q.; Lei, L.; Jiang, X.; Feng, Z.C.; Tang, M.; He, D. Li ion diffusion in $\mathrm{LiAlO}_{2}$ investigated by Raman spectroscopy. Solid State Sci. 2014, 37, 103-107. [CrossRef]

20. Wohlmuth, D.; Epp, V.; Bottke, P.; Hanzu, I.; Bitschnau, B.; Letofsky-Papst, I.; Kriechbaum, M.; Amenitsch, H.; Hofer, F.; Wilkening, M. Order vs. disorder-a huge increase in ionic conductivity of nanocrystalline $\mathrm{LiAlO}_{2}$ embedded in an amorphous-like matrix of lithium aluminate. J. Mater. Chem. A 2014, 2, 20295-20306. [CrossRef]

21. Islam, M.M.; Bredow, T. Interstitial lithium diffusion pathways in $\gamma$ - $\mathrm{LiAlO}_{2}$ : A computational study. J. Phys. Chem. Lett. 2015, 6, 4622-4626. [CrossRef] [PubMed]

22. Bianchini, F.; Fjellvåg, H.; Vajeeston, P. A first principle comparative study of the ionic diffusivity in $\mathrm{LiAlO}_{2}$ and $\mathrm{NaAlO}_{2}$ polymorphs for solid-state battery applications. Phys. Chem. Chem. Phys. 2018, 20, 9824-9832. [CrossRef] [PubMed]

23. Gale, J.D.; Rohl, A.L. The General Utility Lattice Program (GULP). Mol. Simul. 2003, 29, 291-341. [CrossRef]

24. Gale, J.D. GULP: A computer program for the symmetry-adapted simulation of solids. J. Chem. Soc. Faraday Trans. 1997, 93, 629-637. [CrossRef]

25. Mott, N.F.; Littleton, M.J. Conduction in polar crystals. I. Electrolytic conduction in solid salts. Trans. Faraday Soc. 1938, 34, 485-499. [CrossRef]

26. Kuganathan, N.; Iyngaran, P.; Chroneos, A. Lithium diffusion in $\mathrm{Li}_{5} \mathrm{FeO}_{4}$. Sci. Rep. 2018, 8, 5832. [CrossRef] [PubMed]

27. Kuganathan, N.; Kordatos, A.; Kelaidis, N.; Chroneos, A. Defects, Lithium Mobility and Tetravalent Dopants in the $\mathrm{Li}_{3} \mathrm{NbO}_{4}$ Cathode Material. Sci. Rep. 2019, 9, 2192. [CrossRef] 
28. Kuganathan, N.; Sgourou, E.N.; Panayiotatos, Y.; Chroneos, A. Defect Process, Dopant Behaviour and Li Ion Mobility in the $\mathrm{Li}_{2} \mathrm{MnO}_{3}$ Cathode Material. Energies 2019, 12, 1329. [CrossRef]

29. Grimes, R.W.; Busker, G.; McCoy, M.A.; Chroneos, A.; Kilner, J.A.; Chen, S.P. The Effect of Ion Size on Solution Mechanism and Defect Cluster Geometry. Bunsen Ges. Phys. Chem. 1997, 101, 1204-1210. [CrossRef]

30. Varotsos, P.; Alexopoulos, K. Thermodynamics of Point Defects and Their Relation with the Bulk Properties; Amelinckx, S., Gevers, R., Nihoul, J., Eds.; Elsevier: Amsterdam, The Netherlands, 1986.

31. Varotsos, P. Comparison of models that interconnect point defect parameters in solids with bulk properties. J. Appl. Phys. 2007, 101, 123503. [CrossRef]

32. Chroneos, A.; Vovk, R.V. Modeling self-diffusion in $\mathrm{UO}_{2}$ and $\mathrm{ThO}_{2}$ by connecting point defect parameters with bulk properties. Solid State Ion. 2015, 274, 1-3. [CrossRef]

33. Cooper, M.W.D.; Grimes, R.W.; Fitzpatrick, M.E.; Chroneos, A. Modeling oxygen self-diffusion in $\mathrm{UO}_{2}$ under pressure. Solid State Ion. 2015, 282, 26-30. [CrossRef]

34. Sarlis, N.V.; Skordas, E.S. Pressure and temperature dependence of the oxygen self-diffusion activation volume in $\mathrm{UO}_{2}$ by a thermodynamic model. Solid State Ion. 2016, 290, 121-123. [CrossRef]

35. Marezio, M. The crystal structure and anomalous dispersion of $\gamma-\mathrm{LiAlO}_{2}$. Acta Crystallogr. 1965, 19, 396-400. [CrossRef]

36. Kröger, F.A.; Vink, H.J. Relations between the Concentrations of Imperfections in Crystalline Solids. In Solid State Physics; Seitz, F., Turnbull, D., Eds.; Academic Press: Cambridge, MA, USA, 1956; Volume 3, pp. $307-435$.

37. Armstrong, A.R.; Kuganathan, N.; Islam, M.S.; Bruce, P.G. Structure and Lithium Transport Pathways in $\mathrm{Li}_{2} \mathrm{FeSiO}_{4}$ Cathodes for Lithium Batteries. J. Am. Chem. Soc. 2011, 133, 13031-13035. [CrossRef] [PubMed]

38. Nytén, A.; Abouimrane, A.; Armand, M.; Gustafsson, T.; Thomas, J.O. Electrochemical performance of $\mathrm{L}_{\mathrm{i} 2} \mathrm{FeSiO}_{4}$ as a new Li-battery cathode material. Electrochem. Commun. 2005, 7, 156-160. [CrossRef]

39. Politaev, V.V.; Petrenko, A.A.; Nalbandyan, V.B.; Medvedev, B.S.; Shvetsova, E.S. Crystal structure, phase relations and electrochemical properties of monoclinic $\mathrm{Li}_{2} \mathrm{MnSiO}_{4}$. J. Solid State Chem. 2007, 180, 1045-1050. [CrossRef]

40. Liu, H.; Choe, M.J.; Enrique, R.A.; Orvañanos, B.; Zhou, L.; Liu, T.; Thornton, K.; Grey, C.P. Effects of Antisite Defects on $\mathrm{Li}$ Diffusion in $\mathrm{LiFePO}_{4}$ Revealed by Li Isotope Exchange. J. Phys. Chem. C 2017, 121, 12025-12036. [CrossRef]

41. Kempaiah Devaraju, M.; Duc Truong, Q.; Hyodo, H.; Sasaki, Y.; Honma, I. Synthesis, characterization and observation of antisite defects in $\mathrm{LiNiPO}_{4}$ nanomaterials. Sci. Rep. 2015, 5, 11041. [CrossRef]

42. Kuganathan, N.; Kordatos, A.; Anurakavan, S.; Iyngaran, P.; Chroneos, A. $\mathrm{Li}_{3} \mathrm{SbO}_{4}$ lithium-ion battery material: Defects, lithium ion diffusion and tetravalent dopants. Mater. Chem. Phys. 2019, 225, 34-41. [CrossRef]

43. Kordatos, A.; Kuganathan, N.; Kelaidis, N.; Iyngaran, P.; Chroneos, A. Defects and lithium migration in $\mathrm{Li}_{2} \mathrm{CuO}_{2}$. Sci. Rep. 2018, 8, 6754. [CrossRef] [PubMed]

44. Kuganathan, N.; Ganeshalingam, S.; Chroneos, A. Defects, Dopants and Lithium Mobility in $\mathrm{Li}_{9} \mathrm{~V}_{3}\left(\mathrm{P}_{2} \mathrm{O}_{7}\right)_{3}\left(\mathrm{PO}_{4}\right)_{2}$. Sci. Rep. 2018, 8, 8140. [CrossRef] [PubMed]

45. Kuganathan, N.; Kordatos, A.; Chroneos, $\mathrm{A}$. $\mathrm{Li}_{2} \mathrm{SnO}_{3}$ as a Cathode Material for Lithium-ion Batteries: Defects, Lithium Ion Diffusion and Dopants. Sci. Rep. 2018, 8, 12621. [CrossRef] [PubMed]

46. Kuganathan, N.; Kordatos, A.; Chroneos, A. Defect Chemistry and Li-ion Diffusion in $\mathrm{Li}_{2} \mathrm{RuO}_{3}$. Sci. Rep. 2019, 9, 550. [CrossRef] [PubMed]

47. Kuganathan, N.; Tsoukalas, L.H.; Chroneos, A. Defects, dopants and Li-ion diffusion in $\mathrm{Li}_{2} \mathrm{SiO}_{3}$. Solid State Ion. 2019, 335, 61-66. [CrossRef]

48. Dominko, R.; Bele, M.; Gaberšček, M.; Meden, A.; Remškar, M.; Jamnik, J. Structure and electrochemical performance of $\mathrm{Li}_{2} \mathrm{MnSiO}_{4}$ and $\mathrm{Li}_{2} \mathrm{FeSiO}_{4}$ as potential Li-battery cathode materials. Electrochem. Commun. 2006, 8, 217-222. [CrossRef]

49. Kushima, A.; Parfitt, D.; Chroneos, A.; Yildiz, B.; Kilner, J.A.; Grimes, R.W. Interstitialcy diffusion of oxygen in tetragonal $\mathrm{La}_{2} \mathrm{CoO}_{4+\delta}$. Phys. Chem. Chem. Phys. 2011, 13, 2242-2249. [CrossRef]

50. Kuganathan, N.; Chroneos, A. Defects and dopant properties of $\mathrm{Li}_{3} \mathrm{~V}_{2}\left(\mathrm{PO}_{4}\right)_{3}$. Sci. Rep. 2019, 9, 333. [CrossRef]

51. Cahill, L.S.; Chapman, R.P.; Britten, J.F.; Goward, G.R. 7Li NMR and Two-Dimensional Exchange Study of Lithium Dynamics in Monoclinic $\mathrm{Li}_{3} \mathrm{~V}_{2}\left(\mathrm{PO}_{4}\right)_{3}$. J. Phys. Chem. B 2006, 110, 7171-7177. [CrossRef] 
52. Kuganathan, N.; Kordatos, A.; Fitzpatrick, M.E.; Vovk, R.V.; Chroneos, A. Defect process and lithium diffusion in $\mathrm{Li}_{2} \mathrm{TiO}_{3}$. Solid State Ion. 2018, 327, 93-98. [CrossRef]

53. Ruprecht, B.; Wilkening, M.; Uecker, R.; Heitjans, P. Extremely slow Li ion dynamics in monoclinic $\mathrm{Li}_{2} \mathrm{TiO}_{3}$-Probing macroscopic jump diffusion via ${ }^{7} \mathrm{Li}$ NMR stimulated echoes. Phys. Chem. Chem. Phys. 2012, 14, 11974-11980. [CrossRef] [PubMed]

54. Fehr, T.; Schmidbauer, E. Electrical conductivity of $\mathrm{Li}_{2} \mathrm{TiO}_{3}$ ceramics. Solid State Ion. 2007, $178,35-41$. [CrossRef]

55. Kuganathan, N.; Chroneos, A. Defects, Dopants and Sodium Mobility in $\mathrm{Na}_{2} \mathrm{MnSiO}_{4}$. Sci. Rep. 2018, 8, 14669. [CrossRef] [PubMed]

56. Kuganathan, N.; Chroneos, A. $\mathrm{Na}_{3} \mathrm{~V}\left(\mathrm{PO}_{4}\right)_{2}$ cathode material for $\mathrm{Na}$ ion batteries: Defects, dopants and $\mathrm{Na}$ diffusion. Solid State Ion. 2019, 336, 75-79. [CrossRef]

57. Kuganathan, N.; Iyngaran, P.; Vovk, R.; Chroneos, A. Defects, dopants and Mg diffusion in MgTiO3. Sci. Rep. 2019, 9, 4394. [CrossRef] [PubMed]

(C) 2019 by the authors. Licensee MDPI, Basel, Switzerland. This article is an open access article distributed under the terms and conditions of the Creative Commons Attribution (CC BY) license (http://creativecommons.org/licenses/by/4.0/). 